\title{
Lembrar Escrever Esquecer
}

Jeanne Marie Gagnebin

São Paulo: Ed. 34, 2006.

\section{Da escrita de um passado presente}

Há certos livros que acertam o alvo porque miram em outro lugar; o que conseguem atingir nos toca justamente porque desviam seu foco para algo aparentemente distante. Este é o caso do recente livro de Jeanne Marie Gagnebin, Lembrar Escrever Esquecer. Trata-se de uma coleção de ensaios escritos em um período de dez anos, de 1995 a 2004, em diferentes circunstâncias, ora como palestras, mesas-redondas em congressos, ora como capítulos de volumes temáticos. Isso poderia levar a crer que o livro não tem coerência, que seus diversos tempos, objetos e situações de escrita levariam a um estilhaçamento de assuntos e perspectivas, mas é o contrário que acontece. Os momentos de confluência, diálogo e desenvolvimento entre os tex tos são vários e apontam para certa vivacidade do pensamento, como se fossem as próprias idéias que, quase a despeito da autora, insistissem em se escrever em instantes e locais tão distintos.

Começando com Homero, passando por Platão, Kafka e Proust, e chegando a Adorno, Benjamin e Ricouer, Lembrar Escrever Esquecer habita e desdobra o espaço de um paradoxo da memória e da experiência do passado. Como diz a autora, " $[\mathrm{d}]$ e um lado, na esteira de Walter Benjamin, não esquecer dos mortos, dos vencidos, não calar, mais uma vez, suas vozes [...]. De outro, agora seguindo as pegadas de Nietzsche, não cair na ilusão narcísica de que a atividade intelectual e acadêmica possa encontrar sua justificação definitiva nesse trabalho de acumulação - pois o apelo do presente, da vida no presente, também exige que o pensamento saiba esquecer" (: 11-2). Em outras palavras, o imperativo de lembrança é uma condição indispensável para que não se repitam as catástrofes do passado, e a necessidade do esquecimento decorre da impossibilidade de tudo registrar, que acabaria por matar o futuro. Como meio de preservação por excelência, a escrita desempenha papel fundamental nesse paradoxo. Se, por um lado, ela é capaz, de alguma forma, de armazenar o que aconteceu, por outro, sepulta aquilo que haveria de espontaneidade na transmissão oral. É interessante notar que tudo isso já está expresso no título do livro, pois a ordem "natural" é invertida, e o escrever está depois de lembrar e antes de esquecer, recusando assim uma progressão que levaria à salvaguarda tranqüila do passado.

Seria errado pensar que essa tensão que envolve a busca do passado e seu registro leva a um beco sem saída estéril, como se não houvesse nada a 
fazer, senão contemplar a beleza desse impasse. Ao contrário, o que o livro de Gagnebin faz, ao discutir sua temática central em diversos autores, é nos incitar a considerar o nosso próprio presente em relação aos dilemas que nos foram legados pelo passado - a "fidelidade ao passado, não sendo um fim em si, visa à transformação do presente”, diz a autora (: 55). Em Odisséia, por exemplo, vemos a importância da hospitalidade como relação de reconhecimento e respeito pelo outro; é sobre a base dessa relação que se fundaria a própria idéia de cultura, "de entrar em comunicação com o outro e de proceder a uma troca" (: 21), seja este outro a terra-mãe (a cultura como cultivo), os deuses (a cultura como culto) ou o próprio homem (a cultura como receptividade para o diferente). É difícil imaginar tudo isso sem pensar, em algum momento, no problema da imigração hoje em dia, e as medidas restritivas que sistematicamente estão sendo tomadas pelos países ricos para coibi-la.

A mesma coisa também acontece quando nos voltamos para outro ponto central no livro de Gagnebin, a questão do narrar. Seja em seu argumento sobre a importância da autonarração para a constituição da subjetividade em Odisséia (em resposta à leitura de Adorno e Horkheimer), seja em sua ênfase em uma narração que recupere os rastros deixados pelo passado (seguindo Benjamin, o historiador como coletor de restos), as questões levantadas apontam indiretamente para dilemas que vivemos atualmente. Quais são os grupos capazes de narrar, hoje, a sua própria existência, diante da enxurrada de mensagens dos meios de comunicação? E o que dizer da visibilidade dos rastros na era da microeletrônica, que vem abolindo as cartas e fazendo obsoletos os rascunhos?

Também em relação a Auschwitz, um tema aparentemente mais próximo, podemos ver a mesma dinâmica em jogo. Com efeito, a dificuldade em lidar com o campo de concentração é uma miniatura do impulso geral do livro. Por um lado, não se pode esquecer Auschwitz, sob pena de se deixar repetir, de outra maneira, o genocídio; por outro, concentrar-se nele, de forma a esquecer o resto, equivale a ajudar, ainda que indiretamente, a perpetuar as outras catástrofes que incessantemente ocorrem. Se, como disse Adorno, Auschwitz nos impõe o imperativo moral de que a tragédia não mais se repita, isso só faz iluminar a derrota de todos nós em relação aos massacres correntes (como o de Dafur), e também diante daqueles apagados da história (como o dos armênios nas mãos dos turcos).

Nesse contexto, não é de se estranhar que a literatura desempenhe papel tão importante. Em uma interpretação original de $A$ colônia penal, de Kafka, um conto muito conhecido e comentado, Gagnebin salienta a ambigüidade do viajante, que testemunha a morte do oficial, vítima de sua própria máquina bárbara de tortura, que escreve nas costas dos condenados, penetrando cada vez mais profundamente em sua pele até que morram. Essa 
figura, supostamente um representante do mundo civilizado, esquiva-se de expressar qualquer julgamento voluntário a respeito da inumanidade que lhe salta aos olhos. Seu "não" aos pedidos do oficial para que se posicione como contrário à aposentadoria da máquina de tortura vem somente depois de reiterados apelos. Além disso, ao deixar a ilha da colônia penal, o viajante impede que o condenado e o soldado se juntem a ele, obrigando-os, assim, a permanecer na barbárie. Lido dessa forma, o conto nos implica diretamente: como pessoas esclarecidas, quantas vezes já não agimos de forma idêntica à do viajante?

Já em relação a Proust, Gagnebin enfatiza o trabalho da escrita no processo de invocação do passado. $\mathrm{O}$ famoso episódio da madeleine suscita a questão: por que não parar aí, se a felicidade da infância parece voltar ao narrador em toda sua plenitude? Por que são necessárias alguns milhares de páginas a mais? Porque "não é a sensação em si (o gosto da "madaleine" e a alegria por ele provocada) que determina o processo da escrita verdadeira, mas a elaboração dessa sensação, a busca espiritual de seu nome originário; portanto, a transformação, pelo trabalho da criação artística, da sensação em linguagem, da sensação em sentido" (: 154). Essa elaboração está cada vez mais difícil; o trabalho de introspecção que exige e, principalmente, o tempo que demanda estão na contramão da aceleração constante do mundo atual. A crescente exacerbação da experiência de choque e o instantaneismo que a acompanha (como muito bem caracterizou Fredric Jameson) fazem do trabalho proustiano algo tanto mais distante quanto desejável.

Haveria ainda muitos outros pontos a mencionar, como as discussões a respeito da natureza da mímese, do corpo nu, desprotegido, da teoria de Paul Ricoeur, ou da distinção entre literatura e filosofia como formas de expressão. Mas o que foi dito até aqui deve bastar para atiçar a curiosidade do leitor em relação a um livro que, na própria medida que fala de coisas aparentemente tão distantes temporal e culturalmente, não cessa de nos dizer. Não é outra a razão de ser do discurso da história.

Fabio Akcelrud Durão [UNICAMP] 